\title{
FIRST ROOTED, THEN GROUNDED: THE POSITION OF THE CHURCH INSTITUTION IN KUYPER'S ECCLESIOLOGY
}

\author{
Surya Harefa \\ Theological University of Kampen, the Netherlands \\ Korespondensi: shharefa@tukampen.nl
}

\begin{abstract}
This article revisits the position of the institutional church in the ecclesiology of Abraham Kuyper (1837-1920). Following the growing interest in the life and work of Kuyper in North America, some scholars pay attention to the importance of his ecclesiology. However, it is common to consider that Kuyper in his later life preferred the aspect of the church as organism and thus marginalizing the church as institution. After exploring his ecclesiological concept on the distinction of the church as organism and institution, this paper examines several major works of Kuyper on the institutional church written in his later life. Finding that Kuyper consistently viewed the institutional church highly, I argue that his restriction toward the church as insitution is to strengthen and provide a stable position of the institutional church in modern society.
\end{abstract}

KEYWORDS: Kuyper; church as institution; church as organism; public theology.

ABSTRAK: Artikel ini meninjau kembali posisi gereja institusional dalam eklesiologi Abraham Kuyper (1837-1920). Melanjutkan pertumbuhan ketertarikan terhadap kehidupan dan karya Kuyper di Amerika Utara, beberapa ahli memperhatikan pentingnya eklesiologi Kuyper. Namun, merupakan hal yang umum untuk memandang bahwa Kuyper di periode kehidupan belakangannya lebih mementingkan gereja sebagai organisme dan dengan demikian mengesampingkan gereja sebagai institusi. Setelah mengeksplorasi konsep eklesiologis tentang pembedaan gereja sebagai organisme dan institusi, tulisan ini meneliti beberapa karya utama Kuyper mengenai gereja institusional yang ditulis dalam periode kehidupan belakangannya. Berdasar temuan bahwa Kuyper secara konsisten memandang tinggi gereja institusional, penulis berpendapat bahwa pembatasannya terhadap gereja 
sebagai insitusi adalah dalam rangka memperkuat dan memberikan posisi stabil bagi gereja institusional di dalam masyarakat modern.

KATA KUNCI: Kuyper; gereja sebagai institusi; gereja sebagai organisme; teologi publik.

Following the renaissance of Kuyper's research in North America, some scholars pay attention to the importance of his ecclesiology. Although Kuyper is famous for his public theology, after investigating the ecclesiology of Kuyper, John Wood without hesitation states that "Kuyper's public theology was a public theology designed to meet the needs of his free church [concept]." ${ }^{11}$ For him, Kuyper has taught us that "ecclesiology ought to be a first principle of public theology." ${ }^{2}$ Similarly, in his comprehensive chronological and thematic biography of Kuyper, James Bratt acknowledges that Kuyper's "ecclesiology had central importance for Kuyper in its own right" and "marked the crossroads where his twin passions of divine sovereignty and social formation intersected." ${ }^{3}$

Kuyper unified his ecclesial passion and desire to engage the society by distinguishing the aspect of the church as organism and the church as institution. This distinction might be the most important element of his concept of the church. While Henry Zwaanstra regards the distinction as "the heart" of Kuyper's ecclesiology, John Bolt states that the distinction between organism and institution was "a cornerstone of Kuyper's public theology." ${ }^{4}$ In the same vein, Peter Heslam observes it as "a unifying link between the church and the world which would serve his [Kuyper's] twin aims of social and ecclesiastical renewal." ${ }^{5}$

However, many scholars interpret that Kuyper preferred the church as organism and thus marginalizing the church as institution. Bratt asserts that the church in which Kuyper valued was the church organic. ${ }^{6}$ Heslamstates

\footnotetext{
1 John H. Wood Jr., Going Dutch in the Modern Age: Abraham Kuyper's Struggle for a Free Church in the Netherlands (New York: Oxford University Press, 2013), 174.

2 Ibid.

3 James D. Bratt, Abraham Kuyper: Modern Calvinist, Christian Democrat (Grand Rapids: $\quad$ Eerdmans, 2013), 172.

4 John Bolt, A Free Church, A Holy Nation: Abraham Kuyper's American Public Theology (Grand Rapids: Eerdmans, 2001), 427.

5 Peter S. Heslam, Creating a Christian Worldview: Abraham Kuyper's Lectures on Calvinism (Grand Rapids: Eerdmans, 1998), 135.

6 James D. Bratt, "Abraham Kuyper: His World and Work," in Abraham Kuyper: A Centennial Reader, by Abraham Kuyper, ed. James D. Bratt (Grand Rapids: Eerdmans, 1998), 11. However, Bratt also admits that "Kuyper regarded it [the church as institution] as a crucial means nonetheless. Only if the church-institute's word was pure and strong, its ministry undefiled by error or half-heartedness, could the church organic be made vital for its mission in society and culture."
} 
that the distinction between the church as institution and the church as organism is a theological justification to "restrict the activity of the church as institute to its ecclesiastical offices," and to "stress on the far broader task of the church as organism, which was the transformation of human society by bringing it into harmony with the insights provided by the Christian faith." ${ }^{\prime 7}$ More thoroughly, Wood asserts:

There is also a negative lesson to draw from Kuyper's ecclesiology. Kuyper's private church, grounded as it was in conscience, circumscribed by group identity and relativized as a modern organization, obscured the public mandate that the institutional church does have. Kuyper's proposal marginalized the institutional church, yet this church is the church for the world. Its mandate cannot be truncated by any social arrangements, modern or ancient. The preaching of the Word and the sacraments of the Lord, not Christian political parties or colleges or school systems, proclaim a message of hope to the world, the announcement of a light to lighten the Gentiles and the glory of the people Israel-a public mission if ever there was one. ${ }^{8}$

In short, Wood concludes that by the distinction of the church as organism and institution, Kuyper marginalized the institutional church.

This paper attempts to revisit the position of the institutional church in the ecclesiology of Kuyper. First, I will discuss his distinction of the church as organism and institution. Afterward, I will elaborate on the arguments of Wood and explore the statements as well as actions of Kuyper that caused the common interpretation mentioned above. By showing the views of Kuyper on the institutional church in several of his major works written in his later life, I will argue that rather than marginalizing the church institution, Kuyper attempted to strengthen the institutional church in modern society.

\section{The Church as Organism}

For Kuyper, "the Church is a spiritual organism." ${ }^{\prime 9}$ By the term "spiritual," he was emphasizing the heavenly character of the church. The starting-point and the center of the church is in heaven. ${ }^{10}$ This means that the church was "not of this world but from heaven, not from below but from above." ${ }^{11}$ The

\footnotetext{
7 Heslam, Creating a Christian Worldview, 132-35. Cf. Richard J. Mouw, “Culture, Church, and Civil Society: Kuyper for a New Century," The Princeton Seminary Bulletin 28, no. 1 (2007): 56-59; Abraham Kuyper: A Short and Personal Introduction (Grand Rapids: Eerdmans, 2011), 122. His suggestion for a "compensatory strategy" to update Kuyper's views about the church indicates that he also takes the side of this common interpretation.

Wood, Going Dutch, 175.

Abraham Kuyper, Lectures on Calvinism (1931; repr., Grand Rapids: Eerdmans, 1999), 59.

10 Ibid., 59, 62.

11 Abraham Kuyper, "Lord's Day 21 [1893]," in On The Church, ed. John H. Wood Jr. and Andrew M. McGinnis, trans. Arjen Vreugdenhil et al. (Bellingham: Lexham, 2016), 322, 323.
} 
basis of this concept is Kuyper's Christological understanding. For him, Christ, who had ascended to heaven, is the founder, protector, and sustainer of the church. It is "with Him, around Him, and in Him, our Head, is the real Church, the real and essential sanctuary of our salvation." ${ }^{12}$ Thus, the church fully depends on the law of life of the heavenly founder. ${ }^{13}$

Kuyper defined the term "organism" as anything "which its vital parts have produced on their own and which, subject to changes in its form, perpetuates and enlarges its own life."14 He used this term to refer to the body of Christ. ${ }^{15} \mathrm{He}$ explained that this one organic body has Christ as the head, and all the believers as the members. The believers are bonded together by the mystical union with Christ. ${ }^{16}$ Hence, the church is:

an organism insofar as we view it in its hidden unity as the mystical body of Christ existing partly in heaven, partly on earth, partly unborn, having penetrated all peoples and nations, possessing Christ as its natural and glorious head, and living by the Holy Spirit who as a life-engendering and life-maintaining force animates both head and members." ${ }^{17}$

Kuyper also used this term to explain that unity and connectedness of believers. The unity and connectedness come to exist not because those individuals come into a relation with each other, but into "a unity and an organic connectedness" which already existed even before those individuals exist. ${ }^{18}$

Besides referring to the whole mystical body of Christ, Kuyper utilized the concept of the organism to refer to two other senses. ${ }^{19}$ First, it refers to the local churches as the primary manifestation of the church of Christ. Being a part of the organism, each local church has the nature of the entire organism stamped in it. Second, it also expresses the natural relationship between each local church. The church as an organism is a rich concept in Kuyper's hand. With this, he developed the doctrine of the priesthood of all believers into his concept of believers' church and the pluriformity of

12 Kuyper, Lectures on Calvinism, 62. Cf. Michael R. Wagenman, "Abraham Kuyper and the Church: From Calvin to the Neo-Calvinists," in On Kuyper: A Collection of Readings on the Life, Work and Legacy of Abraham Kuyper, ed. Steve Bishop and John H. Kok (Sioux Center: Dordt College Press, 2013), 131.

13 Kuyper, "Lord's Day 21," 323.

14 Abraham Kuyper, “Common Grace [1902-4],” in Abraham Kuyper: A Centennial Reader, ed. James D. Bratt, trans. John Vriend (Grand Rapids: Eerdmans, 1998), 187.

15 Kuyper adopted the concept from Friedrich Schleiermacher (1768-1834) and Richard Rothe (17991867). Both were Germany theologians who derived the terms from German Romantic philosopher, Friedrich Schelling (1775-1854). For a more detailed treatment on the origin of this term, see Heslam, Creating a Christian Worldview, 133.

16 Kuyper, Lectures on Calvinism, 59.

17 Kuyper, "Common Grace," 187. Emphasis original.

18 Ibid., 188

19 Abraham Kuyper, "Tract on the Reformation of the Churches [1883]," in On The Church, ed. John H. Wood Jr. and Andrew M. McGinnis, trans. Arjen Vreugdenhil et al. (Bellingham: Lexham, 2016), §15, 116. 
the church. ${ }^{20}$ For him, there were three reasons for defining the church as an organism: (1) it bears a unique life within herself; (2) it lives according to its own rule and law; (3) its later development is already supplied within its seed..$^{21}$ This organism is "the heart of the church" and the "vital seed" every missionary should bring into the mission field. ${ }^{22}$

Kuyper also used the term organism to allude the whole human race. Since in all human beings were one organism, Christ saved not only some individuals but also the whole human race as one organism. Illustrating the human race as a tree, Kuyper asserted that "many branches and leaves fell off," but "the tree itself shall be saved." ${ }^{23}$ The statement about branches and leaves that fell off is worth observing. This means that in Kuyper's view, there are individuals that are not saved. Thus, his position is not suggesting the salvation of all human beings.

In sum, Kuyper utilized this organic concept to support his emphasis on the heavenly nature of the church and the essence of the church. On the present earth, the church "is found, at most, one generation of believers at a time." ${ }^{24}$ Although the church on earth is always bounded by time and place, the organic body of Christ includes all of the elect from all over the world and all periods. ${ }^{25}$ In Kuyper's view, the essence of the church is the organism that originated in God's sovereign election. ${ }^{26}$

\section{The Church as Institution}

Having asserted that the church organism is the essence of the church, Kuyper continued with emphasizing the need for the institution. From the beginning of the New Testament church, the apostles had made several arrangements and regulations for the church. By doing that, for Kuyper, the apostles gave a form to the church that would keep its existence. ${ }^{27}$ He argued that as "all life among human beings needs analysis and arrangement," the church institution was indispensable. ${ }^{28}$ Moreover, since the church places a

20 Cf. Jasper Vree and Johan Zwaan, Abraham Kuyper's Commentatio (1860): The Young Kuyper about Calvin, a Lasco, and the Church, Vol. I (Leiden: Brill, 2005), 53, 56.

21 Abraham Kuyper, “Rooted and Grounded (1870)," in On The Church, ed. John H. Wood Jr. and Andrew M. McGinnis, trans. Nelson D. Kloosterman et al. (Bellingham: Lexham, 2016), 54.

22 Ibid.

23 Kuyper, Lectures on Calvinism, 59.

24 Ibid., 61; Cf. Abraham Kuyper, "Twofold Fatherland [1887]," in On The Church, ed. John H. Wood Jr. and Andrew M. McGinnis, trans. Nelson D. Kloosterman et al. (Bellingham: Lexham, 2016), 286; Kuyper, "Tract on the Reformation," §14, 114.

25 Kuyper, "Twofold Fatherland," 286; Kuyper, Lectures on Calvinism, 61.

26 Kuyper, "Tract on the Reformation," §19, 129.

27 Kuyper, "Rooted and Grounded," 55.

28 Ibid., 56. Kuyper observed that the case of the Church was also similar to the case of God's revelation, which was organic in essence but still could not dispense with the institution of Israel or the form of 
task on all believers together, "there must be an organization that regulates the mandate for everything that happens in the name of everyone." 29

The institution is a means supplied by God for feeding and expanding the organism. Kuyper put it as follows:

Behold, on Pentecost the Holy Spirit descended - I do not say without preparation, but still immediately - and he created the church among men who could never have brought it forth. But after that miraculous creation, things were different. From now on, it is the church itself through which the Holy Spirit, who dwells within it, expands and unfolds that church. From now on, there is mutual interpenetration, a reciprocal influence. From the organism the institution is born, but also through the institution the organism is fed. ${ }^{30}$

As an example, Kuyper referred to Matthew 28:19-20 and argued that because teaching and baptizing presupposed human conscious arrangement, those actions are not organic operation and hence to implement those actions, one needs a human institution. Therefore, the preaching of the Word and the administration of the sacraments require the institutional church.

For Kuyper, the church is at once an organism and an institution. He believed that as the body of Christ, the church had an inner organic life that flows directly from the Spirit of God. Nevertheless, the church is not only a body but also a house, founded and built by human hands. This building has a solid outward form that shaped and protected the inner organism. One should not separate these two aspects because they exist in "mutual interpenetration, a reciprocal influence." ${ }^{31}$ Using the expression of Ephesians 3:17, Kuyper asserted that the church is "First rooted, then grounded, but both bound together at their most inner core!"32 "Rooted" is the description of the organic life of the church, which "arises not through human artistry but immediately from the hand of the Creator." "Grounded" is the requirement of the institution, which is "drawn not from nature but the work of human hands." 33 "There is no nurture where there is no regularity, no nursery where there is no order. Every sphere of nurture involves organism and institution." ${ }^{34}$ In this way, Kuyper emphasized the importance of both organism and institution aspects of the church.

\footnotetext{
document and writing.

29 Ibid., 55.

30 Ibid., 56.

31 Ibid.

32 Ibid., 58. Emphasis original.

33 Ibid., 50. For Kuyper, metaphors for the former can be found in the parable of the tree with spreading branches that grew from a mustard seed (Matt. 13:31, Mark 4:31, Luke 13:19), the true vine (John 15:1-3), the yeast (Matt. 13:33, Luke 13:21), and the body (Rom. 12:4-5, 1Cor. 12:12). A metaphor for the latter is the constructed house, which is consecrated by the Lord's Spirit to be his temple (1Cor. 3:16, Eph. 2:21), and later expanding to the dimensions of an entire city (Heb. 12:22, Rev. 3:12).

34 Ibid., 57.
} 


\section{Marginalization of the Church Institution}

As we have seen, Wood concludes that by the distinction of the church as organism and institution, Kuyper marginalized the institutional church. For him, Kuyper took up from the institution all direct public responsibilities and limited the institution to engage the world only indirectly. ${ }^{35}$

Wood also argues for a change in the thought of Kuyper in his later life. According to him, Kuyper amended the reciprocal influence between the organism and institution mentioned in his 1870 sermon. Afterward, Kuyper put the relation to be one-way relation: the institution comes from the organism and not the other way around..$^{36}$ He observes that since 1883, Kuyper started introducing a concept of the visible organic church. ${ }^{37}$ This term enabled Kuyper to open the possibility to leave one's corrupted institutional church. He elaborated how believers could move from one church institution to another or, if needed, form a new institution altogether.

Wood illustrates the institution in Kuyper's organism-institution ecclesiology as the clothing of one body, not the body itself. When the church's institutional "clothing" failed to serve its intended purpose, these garments could be exchanged for new ones. ${ }^{38}$ Along with the concept of the institution as the well-being of the church, Kuyper distinguished the church from other religious societies, which is lacking the will to manifest ecclesiastical formation. ${ }^{39}$ Therefore, the church could exist in some forms, even a visible form, without the church institution. The institution was necessary but not essential to the church.

One can see many statements of Kuyper that cause he or she to support this common interpretation. Besides what we have seen in the section of The Church as Organism above, Kuyper did write that the earthly church is merely a "silhouette that can be dimly discerned." 40 He even wrote that "no child of God should imagine that the real Church is here on earth." ${ }^{41}$ In line with that warning, he insisted:

35 Wood, Going Dutch, 172.

36 Ibid., 92.

37 It was a middle term between the church as organism and as institution. For Wood, Kuyper premised the visible church on earth might exist in two forms: (1) as an institution; and (2) as a pre-institutional and extra-institutional gathering of believers existing in organic connection. While Vree dates this term to the 1894 Encyclopedia, and Leeuwen to a series of articles from 1887, Wood believes the concept of the visible organism was present earlier, at least as early as the [1883] Tract (Wood, 86-87).

38 Wood, 90.

39 Ibid., 88-89. For Wood, this concept leads to the understanding of the difference between the visible organic church and the institution was the will to form a church, not in the means of grace.

40 Kuyper, Lectures on Calvinism, 60. Here Kuyper added a description of the heavenly sanctuary as follows: The Altar of Atonement, the incense-Altar of Prayer, and Christ, the High Priest at the Altar.

41 Ibid., 61-62. 
supposing that the institution of the Word or the Reformed church would be the visible church... has resulted in the evil that many are content to be joined to an organized church without having any appreciation for the communion of saints. People then fall into a narrow ecclesiastical attitude-one that bans and bar others and breaks off from them without ever realizing what the communion of saints requires of every brother and every sister. ${ }^{42}$

Hence, he asserted that the visible church "must be distinguished clearly from the organized church or institution." ${ }^{43}$

Although Kuyper did not deny the existence of the church on earth, he believed that the earthly church is the imperfect form of the true and perfect one in heaven. He asserted that the church institute was

an apparatus, a local and temporally constructed institution grounded in human choices, decisions, and acts of the will, consisting of members, offices, and useful supplies. As such it is a phenomenon in the external, visible, and perceptible world. ... [It has the] real substance only insofar as the mystical body of Christ lies behind it and manifests itself through it, however imperfectly. When that ceases to be the case, the institute is no longer a church except in appearance, a false church. ${ }^{44}$

Kuyper continued with asserting that the church organism had been existing before the church institution. The organism provides the substance and value to the institution. ${ }^{45}$ Therefore, the "essence of a visible church is and always remains the invisible church." ${ }^{46}$ The organism is the essence, and the institution is the form.

In addition to that, Kuyper restricted the church institution from direct engagement with society. He stated, "the church of Christ can never exert influence on civil society directly, only indirectly." ${ }^{47}$ The goals of the church should remain as follows:

(1) to assure the church full freedom of action and full authority to maintain its own unique character; (2) to avert any attempt to introduce pagan concepts and ideas into the country's laws, public institutions, and public opinion in place of Christian ones; and (3) to continually expand the dominance of nobler and purer ideas in civil society by the courageous action of its members in every area of life. In a nutshell: what we want is a strong confessional church but not a confessional civil society nor a confessional state. ${ }^{48}$

2 Kuyper, “Lord's Day 21," 362.

43 Ibid., 363.

44 Kuyper, "Common Grace," 187-88.

45 Ibid., 195.

46 Kuyper, "Tract on the Reformation," §14, 111.

47 Kuyper, “Common Grace," 197.

48 Ibid. Emphasis original. 
As a result, the public opinion, the general mindset, the ruling ideas, the moral norms, the laws, and customs would indicate the influence of the Christian faith. Through this, Kuyper hoped for the following:

This influence leads to the abolition of slavery in the laws and life of a country, to the improved position of women, to the maintenance of public virtue, respect for the Sabbath, compassion for the poor, consistent regard for the ideal over the material, and-even in manner-the elevation of all that is human from its sunken state to a higher standpoint. ${ }^{49}$

This indirect way of engagements clearly shows that Kuyper put a limitation to the church institution in the public space.

One also might associate his decision in 1874 to resign from the pastorate office and get involved in many areas of the church organism as an evidence of the marginalization of the institutional church interpretation. Indeed, Kuyper utilized the organic church concept to explain his actions. He developed the organism principle to get and convince his followers about his vision of a free church and the pluriformity of the church. ${ }^{50}$

\section{Revisiting The Church Institution in Kuyper's Works}

Nonetheless, revisiting the works on the church institution written in the later life of Kuyper may lead us to see a different interpretation. ${ }^{51}$ First, Kuyper kept emphasizing the importance of the church as institution in his later life. In Tract of the Reformation, the work that Wood used to show a shift in Kuyper's ecclesiology, Kuyper still stressed that the existence of that essence of the church should be followed by "the will and desire to bring their communion to fuller and purer ecclesiastical manifestation as soon as the opportunity arises." 52 It is the institution that brings the potential essence into its actuality. From this perspective, Kuyper said, "the essence of the church cannot be separated from ecclesiastical office or the means of grace." 53 The essence of a church, "consists, on the one hand, of the group of believers, and on the other hand, of the administration of the means of grace." 54 Therefore, in Kuyper's view, without the institution, a mere gathering of believers is not an ideal visible church.

49 Ibid., 199.

50 Cf. James Eglinton, Trinity and Organism: Towards a New Reading of Herman Bavinck's Organic Motif (London: T\&T Clark, 2012), 196, 200-203.

51 Although there are different ways to classify the life of Kuyper, since this article is dealing with the topic of the marginalization of the church institution, I divide the time before he resigned from the pastoral ministry in 1874 as early life and the time afterward, that is after he took seat in Parliament, as later life.

52 Kuyper, "Tract on the Reformation," §14, 111.

53 Ibid., §14, 114.

54 Ibid., §15, 116. 
By putting the organism as essence and institution as form, Kuyper did not mean despising the institutional church. Indeed he asserted that the institutional church could become deformed and hence believers should stand for a reformation of the church. ${ }^{55}$ Having said this, Kuyper reminded the need to take the decision cautiously. While rebuking those who continue to live in a degenerated church, Kuyper also warned that "it would also be terrible if we would leave or separate ourselves from a church that was still a manifestation of Jesus' body, and thus condemn as synagogue of Satan that which was still an instrument of the Holy Spirit." ${ }^{56}$ As long as the church still preaches the Word and administer the sacrament, one should stay and make efforts for the reformation of that church. Even in case of the existence of idolatry, as he wrote:

I need only to ask: Does the church in which I live, my church, still provide me with the preaching of the Word and the administration of the sacraments, with such a degree of purity that the essence of both means of grace is still present in them? The fact that idolatry exists alongside this tolerably pure administration of the means of grace does not remove the essence of the church. While it does present the consistory with the obligation to cut off this abomination, it does not require a member of the church to leave it. ${ }^{57}$

Moreover, in case of an unavoidable separation from an institutional church, Kuyper urged the need to find or establish a new church institution. "You may not remain on your own. Unless it becomes evident that no church of Christ can manifest itself in your town, you must seek that church; and if it is not there, you must try with God's help to bring it to manifestation." 58 Hence, even after almost ten years after his resignation of pastoral ministry and amid involvement in many areas of the church organism, Kuyper consistently valued the institutional church highly.

Although Kuyper did not mention explicitly, one also can see the interrelated function of the church as institution and organism in his Stone Lectures of 1898. Using the biblical metaphors, he illustrated the church as "a city, set upon a hill, which every man can see afar off" and "a holy salt that penetrates in every direction, checking all corruption." ${ }^{59}$ This illustration included two inseparable activities: gathering and sending. ${ }^{60}$ As this

55 Ibid., §58, 236-37.

56 Ibid., $\$ 58,237$.

57 lbid., $\$ 59,253$.

58 Ibid., §58, 240-41.

59 Kuyper, Lectures on Calvinism, 53.

60 Cf. Wagenman, "Kuyper and the Church," 137. He comments as follows: "If the light remains hidden within the city walls or if the salt remains in the shaker, they are of no effect. Likewise, if the source of the light is extinguished, its rays may travel but will soon fade away; if the storehouse of salt runs empty, the salt which has been used up will lose its saltiness and no longer perform its necessary function. 
gathering and sending function should exist together and continuously, the church organism and institution should exist together and continuously in the thought of Kuyper.

In his Common Grace, written as a series of articles from 1895 to 1901, Kuyper insisted that while common grace prepares the way for particular grace, in turn wherever particular grace starts to influence, common grace yields strong development. Common grace could not do the development by itself; only Christian faith could release the forces of common grace. In this case, common grace is an emanation of particular grace that reaches the areas outside the church. ${ }^{61}$ Kuyper stated that the circumference of the church as organism is "determined by the length of the ray that shines out from the church institute over the life of people and nation." ${ }^{62}$ This statement shows how the late Kuyper consistently emphasized the importance of the church institution. The success of the church organism is not independent of the church institution.

Before proceeding to the next section, it is also important to note that Kuyper had already emphasized the importance of the church organism from his early life. In his 1860 Commentatio, written for an essay competition during his doctoral study, Kuyper defined the church as "a spiritual brotherhood of the children of God." ${ }^{13} \mathrm{He}$ put Christ as the "lively center of the whole organism of the church." ${ }^{\prime \prime 4} \mathrm{He}$ argued that Christ established his church according to the eternal counsel and good pleasure of God without any particular visible external form. Hence, the church "has no external marks or characteristics but is recognized... by the way that they mutually embrace each other with the love of a friend." ${ }^{65} \mathrm{He}$ also used the term to refer to spiritual life kindled by the Spirit of Christ that caused the members of the church "renounced whatever things are vile and vicious." 66 Thus, Kuyper had already privileged the organism over the institution since the

Therefore both concentration and extension must take place in a living, dynamic rhythm for the image to work and the meaning to remain intact."

61 Kuyper, "Common Grace," 169-71.

62 Ibid., 195.

63 Abraham Kuyper, “Commentatio [1860]," in On The Church, ed. John H. Wood Jr. and Andrew M. McGinnis, trans. Todd M. Rester et al. (Bellingham: Lexham, 2016), 13.

64 Ibid., 23. Vree and Zwaan believe that the use of "organism" in the "Commentatio" indicated that Kuyper's model of church was something "new to the Netherlands" because "[n]ot only is the word 'organism' completely lacking in the work of the others, but also, none of them had thought so systematically about the role of the embers of the congregation as such" (Vree and Zwaan, Kuyper's Commentatio, 56-57).

65 Ibid., 13. Cf. Vree and Zwaan, Kuyper's Commentatio, 52. For Kuyper, the visible congregation of Christ is a spiritual community. Here, spiritual means "an elucidation about Jesus Christ as the binding and all-stimulating force within the church." Hence, the church needs not the "body of sacred doctrines" to hold the church together.

66 Ibid., 28. 
1860s. ${ }^{67}$ His emphasis on the church organism is not a new concept that Kuyper acquired in his later life.

The significant shift that occurred in Kuyper's life was not from emphasizing institution to organism, but from organism to institution. Kuyper confirmed that ecclesiological change in his work published in 1873. Recalling his conversion to Calvinism during his ministry in Beesd (1863-1867), Kuyper praised the expression "the church as the mother of the believers" used by John Calvin. ${ }^{68} \mathrm{He}$ commended this phrase as a beautiful image that expresses both the organic and the institutional aspect of the church attractively. ${ }^{69} \mathrm{He}$ firmly believes that to restore the church to be "our mother" was the goal of his life. It is precisely this nurturing character that renders the institution indispensable. After this shift, he consistently emphasized privileged the church as organism without looking down the importance of the church institution.

Second, although Kuyper limited the institutional church from direct political engagement, Kuyper entrusted a broad coverage to the ministry of the church institution. Kuyper did assert that the institutional church should restrict itself in the ministry of the Word. However, his concept of that ministry is far from narrow coverage. In 1883, he urged the church institution to extend its ministry to "those outside its gate" through the work of philanthropy, evangelism, and mission. ${ }^{70}$ This indicates that his limitation to church institution was not a restriction that confined the church only in a private sphere.

It is interesting to note that Kuyper put the diaconal task of the church institution in the first place, preceding the evangelism and mission. This shows the great passion of Kuyper for the diaconal work of the church. In order to establish a significant diaconal ministry, Kuyper suggested electing deacons from those who have stable social status and allowed the institutional church to have a connection with the government. ${ }^{71}$ Again one can see that his concept of limiting the direct involvement of the institutional church with society did not imply isolation from the public life. The

67 Vree and Zwaan, Kuyper's Commentatio, 2. Vree and Zwan point that in Commentatio, "[p]articularly remarkable is the primacy of the church as an organism over the church as an institute."

68 Cf. John Calvin, Institutes of the Christian Religion Vol. 4, trans. Ford L. Battles (Albany: Ages Software, 1998), 4.1.4. Calvin himself took this expression from Cyprian (Calvin, 553. f.n. 10).

69 Subsequently, Kuyper said that "Calvin had founded a church, and through his fixed church form he succeeded in spreading blessings and peace to receptive hearts among all the nations of Europe and across the sea, in town and village, even among the poor and the lowly." Abraham Kuyper, "Confidentially [1873]," in Abraham Kuyper: A Centennial Reader, ed. James D. Bratt, trans. Reinder Bruinsma (Grand Rapids: Eerdmans, 1998), 59-61. Emphasis original.

70 Kuyper, "Tract on the Reformation," §33, 160.

71 Ibid., §25, 146. 
church institution can and should carry its public responsibilities through the diaconal works.

Moreover, Kuyper recommended establishing a special committee under the consistory to supervise the management of the church's asset. ${ }^{72}$ Further, when discussing the relation between the school and the church, Kuyper prohibited the church to take charge of the schools directly. However, he obliged the church to "be involved with the school" by (1) establish, nurture, and maintain schools if there is no school that in accordance with the Word of God; (2) make sure that all poor church members can receive proper education; (3) watch the school whether they conduct proper education "in the purity of the truth, according to the Word of God."73 These mean that the institutional church in the ecclesiology of Kuyper has a sort of responsibility toward the situation of the society.

Kuyper reiterated this broad coverage of ministry of the church institution in his commentary of Heidelberg Catechism, written as a series of articles for weekly The Herald from 1886 to 1894, as well as his 1898 Lectures on Calvinism. In the commentary, after confirming that the sole purpose of the church institution is the ministry of the Word, he elaborated what he meant by the ministry of the Word. This ministry includes not only the preaching of the Word but also the following elements: (1) the administration of sacraments; (2) the response to prayers and song of praise; (3) the church discipline; (4) the mission in one's town as well as in distant lands; (5) the ingathering of offering; (6) love works for the poor. ${ }^{74}$ In the same vein, in Lectures on Calvinism, Kuyper stated that the institutional church should make every effort to do the following: (1) contribute to conversion, which follows the regeneration, by means of the preaching of the Word; (2) brighten the lofty character (sanctification) of the believers which Jesus demands, by the communion of the saints and by the Sacraments; (3) exercise the church discipline to preserve the sanctity of the Covenant of God, and to stress the fact that God is too pure to look upon evil; and (4) practice the service of church philanthropy in the Diaconate. ${ }^{75}$ Although Kuyper placed the diaconal ministry at the fourth place, he emphasized that the church institution should implement this ministry in the context of glorifying God, same as the other three ministries. ${ }^{76}$ Therefore, it is clear that by limiting the church institution to the ministry of the Word, Kuyper did not mean

\footnotetext{
Ibid., $\$ 27,150$.

Ibid., §,34, 161-62.

Kuyper, “Lord's Day 21,” 349.

Kuyper, Lectures on Calvinism, 66-67.

Kuyper, 67.
} 
understating the church institution. The institutional church has many things to do, including engagement with the broader society through the diaconal works.

Ad de Bruijne interestingly argues that in Kuyper's view, the church as institution also forms a sphere with public features. Thus, "it cannot be reduced to the private sphere." ${ }^{\prime 77}$ Since the term institution is a specific modern concept, whose roots lie in the nineteenth-century emergence of civil society, by choosing this notion, says de Bruijne, Kuyper suggested the institutional church as an alternative public community. ${ }^{78}$ De Bruijne also considers that the distinction between private and public itself does not fit the basic structure of Kuyper's theology. Kuyper recognizes but one life that gradually unfolds in a multitude of spheres, all placed under the direct authority of God. ${ }^{79}$

Third, Kuyper envisioned the enhancement of the church institution. Kuyper rejected the concept of a national church. Instead, he longed for a robust confessional church. In his Lectures on Calvinism of 1898, Kuyper emphasized the abnormality of the present condition of human beings. Hence, "religion must necessarily assume a soteriological character." ${ }^{80} \mathrm{In}$ line with Calvin, he insisted on the holiness of God and the destructive power of sin. Sin is not merely an incomplete stage. Human beings need both regeneration and revelation. ${ }^{81}$ Therefore, in Kuyper's view, the church should be a congregation of believers. ${ }^{82}$ Accordingly, the church cannot embrace all people in a nation. Having said this, Kuyper made an interesting disclaimer, "[n]ot one single state, but the whole world is its domain." ${ }^{83}$ While rejecting the national church concept, Kuyper opened the way for the church institution to see a much bigger vision than a national church.

Furthermore, his vision for the institutional church is to be a solid training facility. In his commentary on Heidelberg Catechism, Kuyper stated that the church was the army gathered by Christ to fight against Satan to establish the kingdom of God. He summarized as follows:

77 Ad de Bruijne, “'Colony of Heaven': Abraham Kuyper's Ecclesiology in the Twenty-First Century,” Journal for Markets and Morality 17, no. 2 (2014): 465; Ad de Bruijne, "Not without the Church as Institute: The Relevance of Abraham Kuyper's Ecclesiology for Christian Public and Theological Responsibilities in the Twenty-First Century," in The Kuyper Center Review, Vol. 5: Church and Academy, ed. Gordon Graham (Grand Rapids: Eerdmans, 2015), 77-78.

78 Bruijne, “Colony of Heaven," 464.

79 Ibid.

80 Kuyper, Lectures on Calvinism, 54.

81 Ibid., 55-56.

82 Ibid., 65. However, following the Calvinistic covenantal concept, Kuyper did not exclude the children of believers. Infant baptism incorporates the children in the communion of the church until they become confessors, or "sever themselves from the church by their unbelief."

83 Ibid. Emphasis added. 
Christ gathers his church as a holy army of the living God. He gathers his church in order to establish the kingdom of God through it as his army. That is why this army is called church, that is, ecclesia or called-out, select troops. The church of Christ is his glorious bodyguard, the unit of his personal bodyguards, incorporated under him as the Head of all. ${ }^{84}$

Subsequently, Kuyper illustrated the institutional church as the military camp. It is a place where Christ as the head or the commander of the church gathers and continually "feeds, arms, and trains" the member of his body. This place provides the hope of success for the battle. This shows the concern of Kuyper for the church institution. Limiting the institutional church on the ministry of the Word is on purpose so that the church can focus on accomplishing the task to train its members as a capable army of Christ.

In his Common Grace, Kuyper set four terrains of the common grace: (1) common grace without particular grace; (2) particular grace exclusive from common grace; (3) common grace that illuminated by the particular grace; and (4) particular grace utilized the common grace. In the fourth terrain, Kuyper said, the institutional church could use the development resulted by common grace for the sake of the propagation of particular grace. It is this propagation of particular grace that Kuyper regarded as the "original and primary goal." 85 Therefore, when one puts this vision in the context of the distinction of the church as organism and institution, it is no exaggeration to say that Kuyper also aspired to see the enhancement of the church institution through the engagement of the church organism with the society. His limitation against the church institution is to make the institutional church "will be stronger and more penetrating as the lamp of the gospel is allowed to shine more brightly and clearly in the church institute." ${ }^{86}$ It is a step for a higher goal, namely strengthening the institutional church.

\section{Conclusion}

Considering the facts mentioned in the previous section, saying that Kuyper marginalized the church institution is not doing justice to the ecclesiology of Kuyper. Indeed, Kuyper privileged the church as organism as the essence of the church. He also set several restrictions for the institutional church. However, that does not mean Kuyper disdained the church as institution. While emphasizing the importance of the church as organism, he consistently viewed the church as institution highly, even after his resignation from pastoral ministry. Kuyper consistently entrusted the church institution

84 Kuyper, “Lord's Day 21,” 326.

85 Kuyper, "Common Grace," 189.

86 Ibid., 194. 
with broad coverage of the ministry of the Word. The church institution in Kuyper's view is an active and sovereign church. The restrictions for the institutional church are intended to secure the church institution conducting its function properly in modern society. 